\title{
A Study of Critical Thinking Skills Practice in Collaborative Writing in EFL Context
}

\section{Jitlada Moonma ${ }^{1}$ (D) Chittima Kaweera ${ }^{\star}$}

1,2 The School of Liberal Arts, University of Phayao, Phayao, Thailand. 'Email: jitlada.moon@gmail.com Email:ckaweera.sut@gmail.com

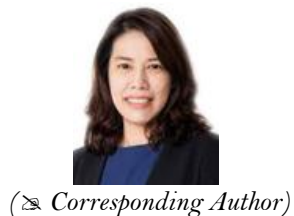

( Corresponding Author)

\begin{abstract}
The present study aims to explore critical thinking from EFL Thai students' perspectives in collaborative writing activity. The subjects were 32 second-year English major students composing paragraph writing in the Writing II course. They were divided into three groups based on their English proficiency: advanced, intermediate, and novice, and data was collected using quantitative and qualitative approaches. The critical thinking skills questionnaire was utilized to collect quantitative data, and the results were analyzed using Mean and Standard deviation. For qualitative data, an interview was used to collect critical thinking skills practice of six students randomly selected. The quantitative results revealed that the highest critical thinking skills practice was found in analyzing (Mean=3.47, $\mathrm{SD}=1.15$ ), followed by evaluating (Mean=3.44, $\mathrm{SD}=1.27$ ), and creating (Mean=3.34, $\mathrm{SD}=.03$ ), respectively. For qualitative results, it was found that the students in the high level of English proficiency group reported they practiced critical thinking by analyzing, evaluating, and creating. They produced a new sentence and a paragraph, selected the best ideas, and categorized the supporting details based on information and ideas from peers. Regarding intermediate and novice level groups, they reported identically that they frequently practiced analyzing and evaluating. Analyzing and assessing were two critical thinking abilities that were commonly utilized. They have to do with comparing and choosing content, as well as elements of arguments and supporting statements. As a result, collaborative writing appeared to promote pupils to use critical thinking skills when writing.
\end{abstract}

Keywords: Attitudes, Critical thinking skills, Critical thinking skill practices, Collaborative writing, Collaborative writing activities, English proficiency levels.

Citation | Jitlada Moonma; Chittima Kaweera (2022). A Study of Critical Thinking Skills Practice in Collaborative Writing in EFL Context. Asian Journal of Education and Training, 8(1): 8-14. History:

Received: 8 November 2021

Revised: 5 January 2022

Accepted: 17 January 2022

Published: 21 January 2022

Licensed: This work is licensed under a Creative Commons Attribution 3.0 License (cc)

Publisher: Asian Online Journal Publishing Group
Funding: The research project is funded by Unit of Excellence, University of Phayao, Phayao, Thailand.

Authors' Contributions: Both authors contributed to the conception and design of the study.

Competing Interests: The authors declare that they have no conflict of interests.

Transparency: The authors confirm that the manuscript is an honest, Transparency: The authors confirm that the manuscript is an honest,
accurate, and transparent account of the study was reported; that no vital accurate, and transparent account of the study was reported; that no vital
features of the study have been omitted; and that any discrepancies from the study as planned have been explained.

Ethical: This study follows all ethical practices during writing.

\section{Contents}

1. Introduction

2. Literature Review .. .9

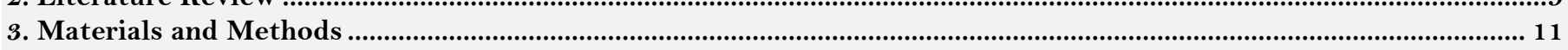

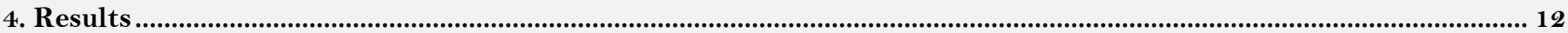

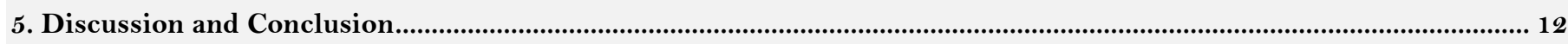

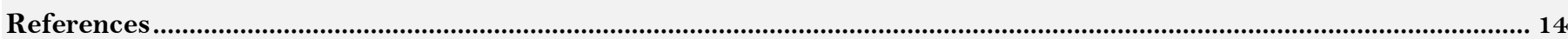




\section{Contribution of this paper to the literature}

This study contributes to existing literature by exploring EFL Thai students' perspectives towards critical thinking skills practiced in collaborative writing activities across different English proficiency levels: advanced, intermediate, and novice. To enhance students' critical thinking skills in writing class, the different kinds of collaborative writing activities could help students enhance and practice their critical thinking skills.

\section{Introduction}

For education at the college level, it is necessary to develop graduates to achieve the learning outcome of making well-informed judgments and who are capable of making connections between their learning and practice. Graduates of the future will need to deal with the unknown and solve problems that may not even exist currently (Boud \& Falchikov, 2006). Critical thinking (CT) is crucial to achieving this outcome and is seen by some as the trademark of a well-educated person and as important for becoming an active and engaged employee and global citizen (Facione, 2010; Fagin, Harper, Baird, Hadfield, \& Sward, 2006; Moore, 2004). Some people believe that university students should have developed their ability to think critically before attending university (Kurfiss, 1988).

Collaborative writing $(\mathrm{CW})$ has received increasing attention in the past decades (Zhang, 2018). In addition, according to Dobao (2012), collaborative writing is a powerful method that encourages critical thinking, peer learning, and active participation toward an end product. It is meaningful interaction and shared decision-making between members of a group using a common set of tools. The practice of collaborative writing has fairly recently in comparison to other, more traditional techniques entered classrooms in response to the need of addressing the issues of structuring, negotiating, and combining ideas in a written form Dobao (2012).

Collaborative activities have been explored in a number of past studies on critical thinking abilities, which are considered a highly important educational goal in many institutions throughout the world. Behar-Horenstein and Niu (2011). In the educational field, from Revised Bloom's taxonomy, critical thinking is incorporated with the concept of higher-order thinking (Anderson \& Krathwohl, 2001). The amount of complexity of cognitive talents can be classified. Higher-order thinking skills correspond to levels of analyzing, evaluating, and creating in this manner.

According to Moore (2013), critical thinking research has tended to characterize the talent in abstract terms, divorcing it from its practical applications. Critical thinking is typically limited to a sequence of mental processes that occur on an individual level, rather than being examined in the context of social interactions, according to Davies and Barnett (2015). As a result, the following part will show how teachers might include critical thinking in the classroom.

\section{Literature Review}

\subsection{Integrating Critical Thinking into Classroom Instruction}

Critical thinking professionals have devised a number of ways for integrating and teaching critical thinking in the classroom. These can be divided into four groups (Abrami et al., 2008). The first of them are ways in which pupils must complete the exercises on their own. The second type of dialogue is one that emphasizes discussion. The third type of training is authentic or grounded instruction, which refers to the selection of real-life problems or situations that students are interested in. Finally, it includes mentorship, which refers to tactics that pair beginners with a subject matter expert. According to Abrami et al. (2008), the best results were obtained when dialogue was combined with real or grounded education. However, there is little research on how teachers implement these tactics in actual classrooms.

However, there are some distinctions between critical thinking and thinking. Breaking down information into smaller pieces is an element of the thinking process. Critical thinking should ideally entail more than just data analysis. When analyzing information, critical thinkers consider external knowledge (Crockett, 2019). Breaking down difficult information to aid in the evaluation of given information may still be part of the information evaluation process. As a result, it appears that critical thinking is entwined with thinking.

\subsection{The Combination of Writing Process and Critical Thinking}

Theoretically, the writing process shares similar characteristics with the critical thinking process listed by Haase (2010). The planning stage reflects skills found in conceptualizing and applying information .At the commencement of the writing process, the writer must use these two critical thinking skills. The writing up step, also known as the translation stage in Flower and Hayes, is where critical thinking abilities of analyzing and synthesizing information are applied (Flower \& Hayes, 1981). Finally, as Flower and Hayes point out, the critical thinking stages' evaluating of information resembles the reviewing stage (Flower \& Hayes, 1981).

Table 1. Relationship between the writing process and critical thinking skills

\begin{tabular}{l|l|l}
\hline The writing process in the working memory & Relationship & Critical thinking skills \\
\hline Planning & & $\begin{array}{l}\text { Conceptualizing } \\
\text { Information } \\
\text { Applying Information }\end{array}$ \\
\hline Translating & & $\begin{array}{l}\text { Analyzing Information } \\
\text { Synthesizing Information }\end{array}$ \\
\hline Reviewing & & Evaluating Information \\
\hline Source Flower and Hayes (1981) and Haase (2010). &
\end{tabular}




\subsection{Related Studies in Critical Thinking Skills}

In recent studies, critical thinking skills development is focused on education research to assist students. One of those is found in the study of Flores, Matkin, Burbach, Quinn, and Harding (2012) looked into how pupils used critical thinking skills. Critical thinking skills were said to be lacking among the students. Once in the workforce, they were unprepared to think critically. Previous research has shown that leaders with low cognitive processing skills are less effective. As critical thinking is linked to constructivism, leadership, and education, several definitions of critical thinking are considered in order to build a general construct to guide the conversation. The majority of pedagogy, according to the report, is content-driven and focused on deep knowledge.

Nold (2017) changed three business classes to add exercises that help students build critical thinking skills, according to research. The Motivated Strategies for Learning Questionnaire (MSLQ) (Pintrich, Smith, Garcia, \& McKeachie, 1991) was used to evaluate changes in 15 learning components during the course of a class, and the results were associated with grades. A modified MSLQ (Boyer \& Usinger, 2012) was used to measure how students self-assess criteria for success at the start and completion of eight-week courses. Results from lessons held over a 15-month period in 2013 and 2014 showed that 14 of the 15 success factors improved, with three of them (intrinsic goal orientation, self-efficacy, and critical thinking) statistically significant. Alidmat and Ayassrah (2017) investigated how critical thinking abilities can be developed in ESP courses using properly selected English writing challenges. In-depth was employed as the instrument in the qualitative investigation. It looked into the perspectives of a group of ten undergraduates on topics connected to their English writing assignments. According to the study's findings, there is little correlation between writing activities in an ESL program and critical thinking skills. This is because the program's writing tasks emphasized mechanical writing rather than critical thought.

The studies of Kaweera (2013) and Kaweera, Yawiloeng, and Tachom (2019) focused on students' opinions on abilities practiced during writing tasks, such as writing, thinking, involvement, and communication, as well as their satisfaction with these activities. Low proficiency students were more likely to appreciate collaborative activities, such as pair or group work, when it came to student happiness. Regarding students' thinking skills, low proficiency pupils were more likely to use them when working in groups. As a result, collaborative work may inadvertently encourage the low and high students to think and collaborate with their peers; however, the study did not focus on critical thinking abilities, which are the deeper thinking skills required in the twenty-first century. Because critical thinking abilities enable students to obtain a more nuanced comprehension of the information they receive and encourage good decision-making and problem-solving in real-world situations, they are highly valued (Dwyer, Hogan, \& Stewart, 2014).

\subsection{Tentative Theoretical Framework}

To characterize critical thinking skills, a provisional framework (see Table 2) was constructed for the current study. A speculative framework on CT (see Figure 1) is built using general CT models as inspiration. It covers all three CT phases. Distinct CT talents and CW are used on different CW steps at different stages. As a result, higher-stage CT is built on the foundation of lower-stage CT. Higher-stage CT skills must be used in conjunction with lower-stage CT skills. To evaluate a text, for example, knowing the literal meaning of the lines is insufficient. Writers must be able to comprehend and interpret the content well. They must then perform some analysis and review in order to determine the inferential meanings between the lines. In a nutshell, higher-stage CT is impossible to achieve without first performing lower-stage CT.
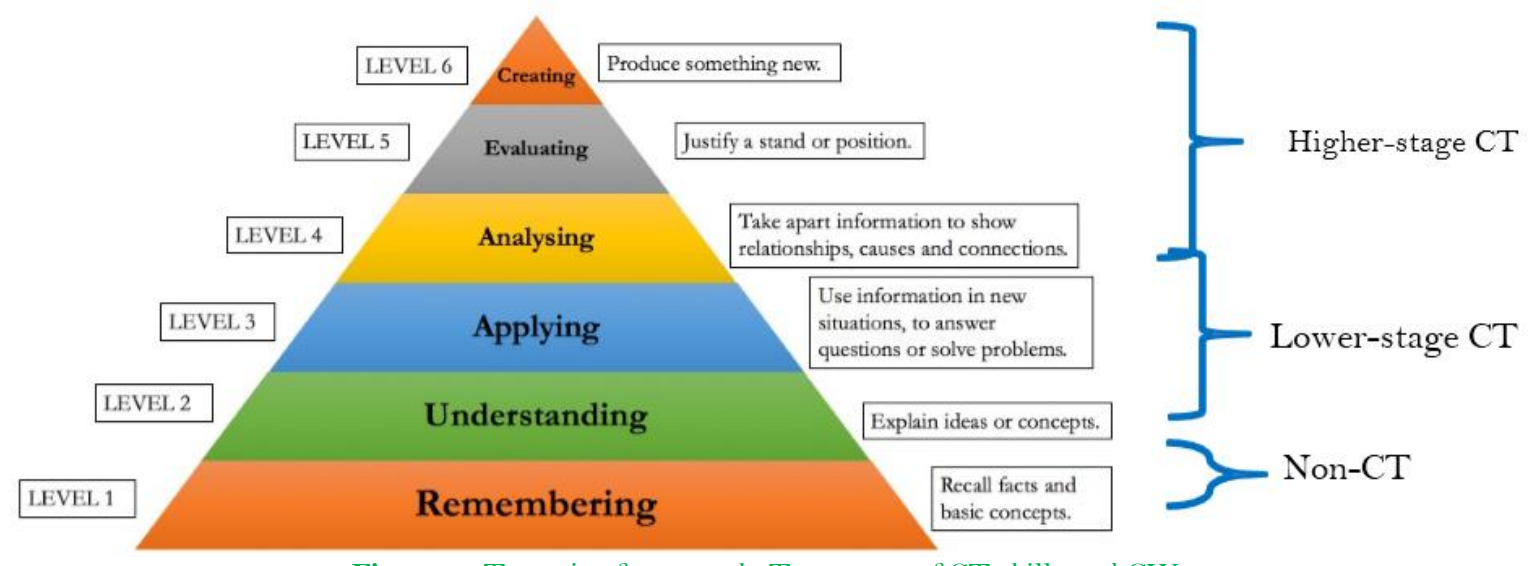

Figure 1. Tentative framework: Taxonomy of CT skills and CW.

Table 2. The six categories of revised Bloom's taxonomy for teaching and learning process.

\begin{tabular}{l|l|l}
\hline Learning Levels & Definition & Sample cues \\
\hline Creating & $\begin{array}{l}\text { Generating new ideas, products, or ways of viewing things, } \\
\text { designing, constructing, planning, producing, inventing. }\end{array}$ & generate, plan, produce \\
\hline Evaluating & $\begin{array}{l}\text { Justifying a decision, checking, hypothesizing, critiquing, } \\
\text { experimenting, judging }\end{array}$ & check, critique, judge \\
\hline Analyzing & $\begin{array}{l}\text { Breaking information into parts to explore understanding } \\
\text { and relationships, comparing, organizing, deconstructing, } \\
\text { interrogating, finding }\end{array}$ & Differentiate, organize, attribute \\
\hline Applying & $\begin{array}{l}\text { Using the information in another familiar situation, } \\
\text { implementing, carrying out, using, executing }\end{array}$ & Execute, implement, apply \\
\hline Understanding & $\begin{array}{l}\text { Explaining ideas or concepts, interpreting, summarizing, } \\
\text { paraphrasing, classifying, explaining }\end{array}$ & $\begin{array}{l}\text { Explain, } \\
\text { summarize, infer, compare, explain, }\end{array}$ \\
\hline Remembering & $\begin{array}{l}\text { Recalling information, recognizing, listing, describing, } \\
\text { retrieving, naming, finding }\end{array}$ & Recall, recognize, write, list, label \\
\hline
\end{tabular}

Source: Anderson and Krathwohl (2001). 


\section{Materials and Methods}

\subsection{Participants}

The participants in this study were 32 second-year English major students studying English as a foreign language at a northern Thai university (13 males and 19 females), ranging in age from 19 to 21 , with an average of 20. All of them were not natural English speakers. All of the participants were assigned to the same Writing II class. Before entering university, the majority of them had spent more than ten years studying English in schools. They were divided into three competency levels based on their performance in Writing I: advanced, intermediate, and novice. Table 3 displays the number of students in each grade level.

Table 3. Students' different levels of English proficiency

\begin{tabular}{l|c|c|c|c}
\hline English Proficiency Levels & Novice & Intermediate & Advanced & Total \\
\hline Numbers of Students & 18 & 8 & 6 & 32 \\
\hline Percentage & 56.25 & 25 & 18.75 & 100 \\
\hline
\end{tabular}

3.2. Research Question

The purpose of this study is to explore the levels of the students' attitudes towards critical thinking skills practice in collaborative writing activities. Therefore, a research question was: What are the levels of the students' critical thinking skills practiced in collaborative writing?

\subsection{Instruments}

\subsubsection{Questionnaire}

The six levels of learning stated by Revised Bloom (1956) and Anderson and Krathwohl (2001) and the concept of collaborative learning proposed by Vygotsky (1978) were used as a framework to develop the questionnaire. The questionnaire was constructed from their studies and categorized into 3 stages of critical thinking: creating, evaluating, and analyzing. The instrument utilized the 5 -Point Likert scale $(1=$ The Least, $2=$ Less, $3=$ Neutral, $4=$ Much, and $5=$ The Most) to avoid central tendency bias Kostoulas, Nielsen, Browne, and Leontides (2013). To provide the participants with a better understanding of the questionnaire contents, the items were in Thai. Table 4 shows the questionnaire.

\begin{tabular}{|c|c|c|c|c|c|c|}
\hline No. & Statements & The Most & Much & Neutral & Less & The Least \\
\hline \multicolumn{7}{|c|}{ Creating } \\
\hline 1 & $\begin{array}{l}\text { I constructed new sentences, using what has been } \\
\text { learned from the members. }\end{array}$ & & & & & \\
\hline 2 & $\begin{array}{l}\text { I collected all the information and designed a } \\
\text { paragraph according to ideas shared by the members. }\end{array}$ & & & & & \\
\hline \multicolumn{7}{|c|}{ Evaluating } \\
\hline 3 & $\begin{array}{l}\text { I made decisions and critiqued the sentences which } \\
\text { involved or did not involve the topic. }\end{array}$ & & & & & \\
\hline 4 & $\begin{array}{l}\text { I selected the appropriate ideas which were } \\
\text { brainstormed by the members. }\end{array}$ & & & & & \\
\hline \multicolumn{7}{|c|}{ Analyzing } \\
\hline 5 & $\begin{array}{l}\text { I broke information into parts to explore better } \\
\text { understanding such as arguments, supporting } \\
\text { evidence, thesis statements, reasons, etc. }\end{array}$ & & & & & \\
\hline 6 & $\begin{array}{l}\text { I categorized the types of ideas shared by members } \\
\text { such as supporting or arguments. }\end{array}$ & & & & & \\
\hline Tota & & & & & & \\
\hline
\end{tabular}

\subsubsection{Semi-Structured Interview}

Also, an open-ended question: What are your attitudes towards critical thinking skills practicing in collaborative writing? was applied to elicit qualitative information in the interview sessions.

\subsection{Validity and Reliability of the Instruments}

Three experts assessed the questionnaire using the Index of Item Objective Congruence (IOC). The IOC was set to 1.00 .

\subsection{Data Collection}

The information was gathered during Writing II of the 2019 academic year at a university in northern Thailand. Following ethical approval, they were only collected once. The questionnaire was handed out at the end of class, and data collecting took roughly 20 to 30 minutes. Following that, six students were interviewed in semistructured interviews ( 2 from advanced students, 2 from intermediate students, and 2 from novice groups).

\subsection{Ethical Approval}

The present study is approved. The certificate number of permission is $2.1 / 004 / 63$, and it was issued by the University of Phayao Human Ethics Committee for Ethical Considerations Involved in Research on Human Subjects. The public was informed of the research objectives and requested to participate voluntarily before data was collected. Following that, the volunteers who agreed to participate in the study signed the consent form. The surveys were kept in a secure location, and the data was logged on a computer that required a password to access. The information will be retained for three years. A paper shredder will be used to destroy the hard copy of the data, and the data's soft files will be erased. 


\subsection{Data Analysis}

According to the study's objective, the data analysis technique was divided into three parts.

Part 1: The questionnaire was used to figure out the students' demographic data from part one of the surveys in order to determine the critical thinking skills exercise. Students' attitudes were examined at five levels using mean and standard deviation. The following criteria were used to interpret mean values:

$5.00-4.21=$ students have the highest level of critical thinking skills practice.

$4.20-3.41=$ students have a high level of critical thinking skills practice.

$3.40-2.61=$ students have a neutral level of critical thinking skills practice.

$2.60-1.81=$ students have less level of critical thinking skills practice.

$1.80-1.00=$ students have the least level of critical thinking skills practice.

Part 2: The qualitative data was collected from the six students' attitudes across all proficiency levels (2 novices, 2 intermediates, and 2 advanced levels) towards critical thinking skills practice. Semi-structured interviews were used.

\section{Results}

The Levels of Students' Attitudes towards Critical Thinking Skills Practices in Collaborative Writing.

The findings of the quantitative and qualitative analyses were administered concerning the research question: What are the students' attitudes levels towards critical thinking practice in CW activities?

Table 5. The levels of students' attitudes towards critical thinking skills practice in collaborative writing.

\begin{tabular}{|c|c|c|c|c|}
\hline No. & Statements & Mean & SD & Meaning \\
\hline \multicolumn{5}{|c|}{ Creating } \\
\hline 1 & I produced new sentences, using what has been learned from the members. & 3.31 & 1.56 & Average \\
\hline 2 & $\begin{array}{l}\text { I collected all the information and designed a paragraph according to ideas shared } \\
\text { by the members. }\end{array}$ & 3.38 & 1.24 & Average \\
\hline \multicolumn{2}{|c|}{ Total } & 3.34 & 0.03 & Average \\
\hline \multicolumn{5}{|c|}{ Evaluating } \\
\hline 3 & $\begin{array}{l}\text { I made decisions and critiqued the sentences which involved or did not involve the } \\
\text { topic. }\end{array}$ & 3.47 & 1.13 & High \\
\hline 4 & I selected the appropriate ideas which were brainstormed by the members. & 3.41 & 0.50 & High \\
\hline \multicolumn{2}{|c|}{ Total } & 3.44 & 1.27 & High \\
\hline \multicolumn{5}{|c|}{ Analyzing } \\
\hline 5 & $\begin{array}{l}\text { I broke information into parts to explore better understanding such as arguments, } \\
\text { supporting evidence, thesis statements, reasons, etc. }\end{array}$ & 3.44 & 0.62 & High \\
\hline 6 & $\begin{array}{l}\text { I categorized the types of ideas shared by members such as supporting or } \\
\text { arguments. }\end{array}$ & 3.50 & 0.67 & High \\
\hline \multicolumn{2}{|c|}{ Total } & 3.47 & 1.15 & High \\
\hline
\end{tabular}

Table 5 demonstrated critical thinking skills practice in collaborative writing. The total mean score was average (Mean $=3.31, \mathrm{SD}=0.97)$. Four of the items had a high mean, while two of them had an ordinary mean. No. 6 was the item with the highest mean. 'I categorized the many types of opinions that members offered, such as supporting or opposing ideas.' whereas No. 1 'I produced new sentences, using what has been learned from the members.' gained the lowest mean (Mean $=3.31, \mathrm{SD}=1.56)$.

\subsection{The Students' Attitudes towards Critical Thinking Skills Practice in Collaborative Writing}

The semi-structured interviews were conducted in the second phase to elicit more details of how students perceived critical thinking skill practice in a process-based approach writing class. Six students with different English proficiency levels were selected to participate in this interview session. Students $1-2(\mathrm{~S} 1-\mathrm{S} 2)$ were randomly drawn from the novice groups, students $3-4(\mathrm{~S} 3-\mathrm{S} 4)$ from the intermediate groups, and students $5-6$ (S5 - S6) from the advanced groups.

When it came to pair writing tasks, novice and intermediate students said they practiced comparing and contrasting facts from friends' content. They did not, however, produce many sentences since they did not feel confident enough to compose an entire paragraph. Advanced pupils, on the other hand, stated that they built their paragraphs on the information supplied by their companions. To develop a finished paper, they studied and picked information from their colleagues.

Regarding group activities, all students reported that the activity encouraged their critical thinking skills in terms of analyzing, evaluating, and sometimes creating. Advanced students said that they chose peers' ideas before writing them in a paragraph. Novice students separated ideas that related to the topic before they produced new sentences. Similar to intermediate students, they also classified and designed all information from peers into a paragraph. Since group activities encouraged participation among friends, students categorized and selected suitable ideas to reach an agreement and wrote their papers. The advanced students realized that their critical thinking skills were improved in terms of analyzing, evaluating, and creating.

In brief, critical thinking abilities such as analyzing and evaluating were commonly used in collaborative writing, according to the interview sessions. They have to do with comparing and choosing content, as well as elements of arguments and supporting statements. In terms of analyzing and assessing, novice and intermediate students claimed they used critical thinking abilities regularly. Advanced students, on the other hand, created a new phrase and paragraph, chose the finest ideas, and organized the supporting elements using information and suggestions from peers.

\section{Discussion and Conclusion}

The purpose of this study was to discover whether collaborative writing could measurably influence critical thinking practice in a second-year English major in a northern Thai university. 


\subsection{The Levels of Students' Attitudes towards Critical Thinking Skills Practices in Collaborative Writing}

The findings of the study revealed that the levels of the students' attitudes towards CT practice in CW (pairs and groups) were at an average level. The present study contrasts with the findings of Alidmat and Ayassrah (2017) study which revealed that there was a low correspondence between writing tasks contained in the ESL program and critical thinking skills. They suggested that the writing tasks featured in the program pursued more mechanical writing than thinking. Figure 2 shows the levels of the students' attitudes of the present study.

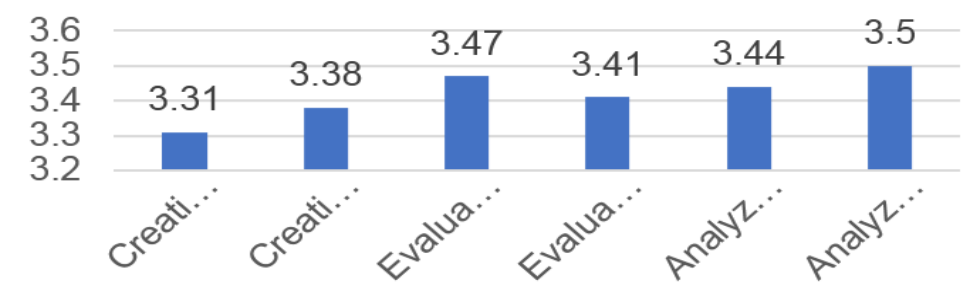

- The Levels of the Student' Attitudes towards Critical Thinking Skills Practice

Figure 2. The levels of the students' attitudes towards critical thinking skills practice.

The reasons that the students' attitudes levels were at average (Mean $=3.31$ ) might be due to reasons, firstly, CW fosters the students for clearly stating ideas and layout arguments in such a way as to cultivate higher-order thinking. Secondly, CW demands that students think ahead, rethink their wording or organization with peers to ensure that their paper meets a specific goal: to argue. Finally, CW or team writing is the process of producing a written work as a group. Each student is required to share ideas and work together to complete their tasks. Therefore, CW seemed to encourage the students to practice CT skills in the writing process even if it was not at a very high level. One problem that might impede the practicing of CT in $\mathrm{CW}$ writing in this study could be the focus on form in writing which is in line with the study of Alidmat and Ayassrah (2017) which suggested that the students focused on form more than thinking. In addition, Flores et al. (2012) confirmed that CT skills were improved the most in the pedagogy which related to content-based. Therefore, teachers should encourage students to think both critically and creatively.

\subsection{The Students' Attitudes towards Critical Thinking Skills in Collaborative Writing}

Based on the interview results, the students considered their CT skills improved, especially in advanced students. One of them stated "I frequently chose friends' ideas before writing them in a paragraph. I also frequently analyzed the sentences and phrases given by friends. After selecting and gathering all ideas, I produced a paragraph. I am also concerned about grammatical rules and structures. I had to decide and edit the sentences shared by peers." "I think collaboration in writing encouraged and improved my critical thinking skills better than individual writing".

Regarding the intermediate group, one of them reported "I practiced frequently the skills of analyzing and evaluating. I selected the sentences or words shared by friends. Sometimes I create sentences. Therefore, I think collaboration in writing helped me to think critically."

From the novice group, a student stated "I frequently practiced comparing and contrasting information related to the content shared by friends. I did not produce many sentences as I was not self-confident to write a whole paragraph. Moreover, I was worried about the grammatical rules". However, I think collaborative writing activities enhanced my critical thinking skills even if it was not at a very high level. I think concerns about grammatical rules sometimes impede my creative thinking."

The results were in line with Nold (2017) who indicated that students from collaborative groups outperformed their writing by practicing CT skills of analysis, evaluation, and creation.

The practice of CT in CW was confirmed by the results of the observation part. They practiced higher-order thinking: analyzing, evaluating, and creating a written argument. However, they also practiced lower-order thinking: applying, understanding, and remembering. When writing individually, all students said that it did not encourage them to practice their critical thinking skills as they had no chance to participate, share or discuss ideas with friends. Vygotsky (1978) said that more interactive activities would promote cognitive growth, such as productive discussions, constructive feedback, and collaboration with others. However, based on the observation data, the students practiced all levels of thinking skills. Therefore, it seemed that higher-stage CT cannot be achieved without lower-stage CT. Figure 4 shows the relationship between lower- and higher-order thinking and how basic comprehension, critical thinking, and creative thinking relate to each other in the writing classroom.

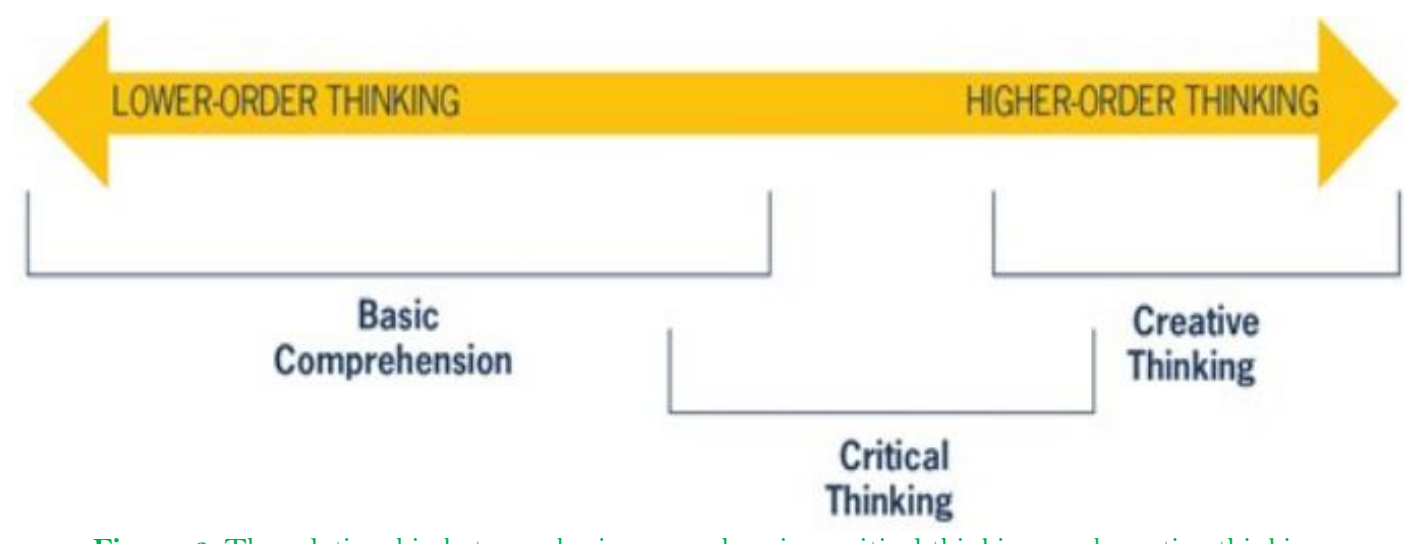

Figure 3. The relationship between basic comprehension, critical thinking, and creative thinking. Source: Diagram from Dummett and Hughes (2019). 
Consequently, to enhance students' critical thinking skills in writing class, writing teachers should consider different kinds of writing activities and encourage creative thinking that could help students enhance and practice their critical thinking skills. Finally, it's worth emphasizing that the scale of lower/higher-order thinking is horizontal. Many other depictions of levels of thought show it as a vertical line (Dummett \& Hughes, 2019). It appears to imply that lower-order thinking is somehow 'lesser' or something that must be finished before higherorder thinking can be asked of students. This is not the case. Knowledge and comprehension are essential components of learning and are in no way inferior. Furthermore, in the classroom, thinking isn't a succession of steps where we move from lower to higher on a scale. A good language lesson might start with a creative thinking exercise, then move on to video comprehension work, and finally a critical thinking class discussion. As a result, the cognitive process is rarely linear.

\subsection{Future Studies}

For future studies, it is important to examine learners 'involvement in different aspects of the task in CW. It may be worthwhile to look at the relationship between students' views and the quantitative assessment of their collaboratively written paper. This would give a more complete picture of how important learner attitude is in achieving the anticipated benefits of $\mathrm{CW}$. Because motivation and attitude are frequently studied together by researchers.

\section{References}

Abrami, P. C., Bernard, R. M., Borokhovski, E., Wade, A., Surkes, M. A., Tamim, R., \& Zhang, D. (2008). Instructional interventions affecting critical thinking skills and dispositions: A stage 1 meta-analysis. Review of Educational Research, 78(4), 11021134.Available at: https://doi.org/10.3102/0034654308326084.

Alan, C. (2006). Assessment of the critical thinking skills of student radiographers. Radiography, 12(2), 88-95.Available at: https://doi.org/10.1016/j.radi.2005.03.004.

Alidmat, A. O. H., \& Ayassrah, M. A. (2017). Development of critical thinking skills through writing tasks: Challenges facing maritime english students at Aqaba College, AlBalqa Applied University, Jordan. International Journal of Higher Education, 6(3), 8290.Available at: https://doi.org/10.5430/ijhe.v6n3p82.

Anderson, L. W., \& Krathwohl, D. D. (2001). A taxonomy for learning, teaching and assessing: A revision of Bloom's taxonomy of educational objectives. New York: Longman.

Behar-Horenstein, L. S., \& Niu, L. (2011). Teaching critical thinking skills in higher education: A review of the literature. Journal of College Teaching \& Learning (TLC), 8(2), 25-41.Available at: https://doi.org/10.19030/tlc.v8i2.3554.

Bloom, B. S. (1956). Taxonomy of educational objectives: The classification of educational goals. handbook 1; Cognitive Domain (pp. 7-8). New York: David McKay Co. Inc.

Boud, D., \& Falchikov, N. (2006). Aligning assessment with long-term learning. Assessment E Evaluation in Higher Education, 31(4), 399413.Available at: https://doi.org/10.1080/02602930600679050.

Boyer, N., \& Usinger, P. (2012). Tracking pathways to success: Identifying learning success factors across course delivery formats. International Journal of Self-Directed Learning, 9(1), 24-37.

Crockett, L. (2019). Critical thinking vs analytical thinking vs creative thinking. Wabisabi Learning. Retrieved from: https://www.wabisabilearning.com/blog/critical-thinking-vs-analytical-thinking-vs-creative-thinking.

Davies, M., \& Barnett, R. (2015). The Palgrave handbook of critical thinking in higher education. New York: Springer.

Dobao, A. F. (2012). Collaborative writing tasks in the L2 classroom: Comparing group, pair, and individual work. Journal of Second Language Writing, 21(1), 40-58.Available at: https://doi.org/10.1016/j.jslw.2011.12.002.

Dummett, P., \& Hughes, J. (2019). Critical thinking in ELT: A working model for the classroom. Boston: National Geographic Learning.

Dwyer, C. P., Hogan, M. J., \& Stewart, I. (2014). An integrated critical thinking framework for the 21 st century. Thinking Skills and Creativity, 12(5), 43-52.

Facione, P. A. (2010). Critical thinking: What it is and why it counts? Insight Assessment, 1-24. Millbrae, California: The California Academic Press.

Fagin, B., Harper, J., Baird, L., Hadfield, S., \& Sward, R. (2006). Critical thinking and computer science: Implicit and explicit connections. Journal of Computing Sciences in Colleges, 21(4), 171-177.

Flores, K. L., Matkin, G. S., Burbach, M. E., Quinn, C. E., \& Harding, H. (2012). Deficient critical thinking skills among college graduates: Implications for leadership. Educational Philosophy and Theory, 44(2), 212-230.Available at: https://doi.org/10.1111/j.14695812.2010.00672.x.

Flower, L., \& Hayes, J. R. (1981). A cognitive process theory of writing. College Composition and Communication, 32(4), $365-387$.

Haase, F.-A. (2010). Categories of critical thinking in information management. A study of critical thinking in decision making processes. Nómadas. Critical Journal of Social and Juridical Sciences, 27(3), 257-275.

Kaweera, C. (2013). Collaborative writing: A comparative study from EFL students' perspectives. Paper presented at the Proceedings in the 7 th International Academic Research Conference on Sustainable Local Development towards ASEAN Community, 70-85. Thailand: Uttaradit Rajabhat University.

Kaweera, C., Yawiloeng, R., \& Tachom, K. (2019). Individual, pair and group writing activity: A case study of undergraduate EFL student writing. English Language Teaching, $12(10), 1-13$.

Kostoulas, P., Nielsen, S., Browne, W. J., \& Leontides, L. (2013). Sample size estimation to substantiate freedom from disease for clustered binary data with a specific risk profile. Epidemiology \& Infection, 141(6), 1318-1327.

Kurfiss, J. G. (1988). Critical thinking: Theory, research, practice, and possibilities. ASHE-ERIC Higher Education Reports. Washington: The George Washington University.

Moore, T. (2004). The critical thinking debate: How general are general thinking skills? Higher Education Research $\mathcal{E}^{2}$ Development, 23(1), 318.

Moore, R. (2013). Basil bernstein: The thinker and the field. London: Routledge.

Nold, H. (2017). Using critical thinking teaching methods to increase student success: An action research project. International Journal of Teaching and Learning in Higher Education, 29(1), 17-32.

Pintrich, P., Smith, D., Garcia, T., \& McKeachie, W. (1991). A manual for the use of the motivated strategies for learning questionnaire (MSLQ). Technical Report No. 91-B-004, United States Office of Educational Research and Improvement, 1-77.

Vygotsky, L. (1978). Interaction between learning and development. Readings on the Development of Children, 23(3), 34-41.

Zhang, M. (2018). Collaborative writing in the EFL classroom: The effects of L1 and L2 use. System, 76(1), 1-12. 